\title{
Regulatory effect of steroid hormones and fetal tissues on expression of oxytocin receptor in the endometrium of late pregnant ewes
}

\author{
S. T. Leung and D. C. Wathes* \\ Department of Veterinary Basic Sciences, The Royal Veterinary College, Hawkshead Road, Potters Bar, Hertfordshire EN6 1NB, UK
}

\begin{abstract}
Oxytocin receptors play an important role in the establishment of pregnancy and parturition in ruminants. Previous studies in cyclic and early pregnant ewes have indicated that receptor concentrations are regulated by steroid hormones and fetal secretory products. This study investigated the effect of oestradiol and progesterone, or co-culture with placenta or corpus luteum on oxytocin receptor expression. Endometrial explants from late pregnant ewes were cultured for up to $96 \mathrm{~h}$ in various treatment combinations. After culture, tissues were subjected to in situ hybridization and autoradiography with ${ }^{125} \mathrm{I}$-labelled oxytocin receptor antagonist to localize and measure the expression of oxytocin receptor mRNA and protein. Results were quantified as absorbance units from autoradiographs. Oxytocin receptors were confined to the endometrial luminal epithelium and both mRNA and ${ }^{225}$ I-labelled oxytocin receptor antagonist binding were upregulated spontaneously in basic serumfree medium. Upregulation occurred earlier in the presence of oestradiol $\left(0.1 \mu \mathrm{mol} \mathrm{l}^{-1}\right)$ but the final receptor concentration was similar to that found in the basic medium. Continuous progesterone treatment $\left(1 \mu \mathrm{mol} \mathrm{l}^{-1}\right)$ and co-culture with corpus luteum both delayed the increase in oxytocin receptor mRNA, but a short initial $(4 \mathrm{~h})$ period in progesterone-free basic medium resulted in loss of the inhibitory effect. Co-culture with placental tissues had no effect. In conclusion, oxytocin receptor expression in the luminal epithelium increased immediately on removal from the maternal environment. This occurred regardless of treatment and did not require the presence of steroid hormones, but could be accelerated or delayed by oestradiol and progesterone, respectively. There may be an additional inhibitory factor present in the corpus luteum.
\end{abstract}

\section{Introduction}

Inhibition of the development of oxytocin receptors plays an important role in the establishment of pregnancy (Flint et al., 1994a; Wathes and Lamming, 1995), whereas induction of oxytocin receptors during labour facilitates delivery of the fetus (Fuchs et al., 1981; Pimental et al., 1989; Sugimoto et al., 1997). The expression pattern of oxytocin receptors in the uterus of sheep and cows has been studied throughout the oestrous cycle (Fuchs et al., 1990; Ayad et al., 1991; Stevenson et al., 1994) and at parturition (Fuchs et al., 1992a,b; Wathes et al., 1996a; Wu et al., 1996). Studies in vitro and in vivo have led to the general belief that oxytocin receptor expression is regulated principally at the transcriptional level, and that oestrogen and progesterone are important positive and negative regulators, respectively (Soloff, 1985).

In early gestation in sheep, oxytocin receptor expression is also inhibited by interferon $\tau$ which is produced by the trophoblast between days 10 and 21 of pregnancy (Roberts $e t$ al., 1992; Stewart et al., 1992). Low expression of oxytocin

*Correspondence.

Revised manuscript received 8 October 1998. receptors appears in the ovine endometrial luminal epithelium after about 21 days of pregnancy, when interferon $\tau$ production ceases, and remains until parturition when further upregulation occurs (Wathes et al., 1996a; Wu et al., 1996). Although progesterone may be responsible for the suppression of oxytocin receptors throughout pregnancy, there is evidence to indicate that the fetus also has a local influence on oxytocin receptor expression (Cerbito et al., 1997; Parry et al., 1997). Unknown factors in addition to progesterone secreted from luteal tissues have also been implicated in inhibiting the expression of oxytocin receptors in the endometrium of cyclic sheep (Sheldrick et al., 1993).

The aim of this study was to elucidate the possible roles of a variety of putative regulatory agents on the expression of oxytocin receptors in late pregnant sheep using endometrial explant cultures. The experiments were classified into two sections: (i) treatments with the steroid hormones oestradiol and progesterone in various concentrations and combinations; and (ii) co-culture of endometrium with fetal cotyledonary tissues, allantochorion and corpus luteum. The expression of oxytocin receptor mRNA and binding activity were analysed by in situ hybridization and autoradiography with ${ }^{125} \mathrm{I}-$ labelled oxytocin antagonist, respectively.

Downtoaded from Bioscientifica.com at $04 / 26 / 2023$ 12:33:53PM 


\section{Materials and Methods}

\section{Reagents}

Chemicals were purchased from Sigma Chemical Co. (Poole) or Merck/BDH (Poole) unless otherwise specified.

\section{Tissue collection and culture}

Clun Forest ewes were mated at natural oestrus and killed by an overdose of pentobarbitone sodium administered i.v. (Euthatal; Rhone Merieux, Tallaght, Dublin) at 130-138 days of gestation. The mean duration of gestation is 147 days. The entire uterus was collected immediately, opened in a laminar flow hood and the fetus removed. Pieces of intercotyledonary endometrium and placentome were dissected and frozen in isopentane immersed in liquid nitrogen. The samples were collected within $15 \mathrm{~min}$ after the animals were killed (time 0 ) and stored at $-80^{\circ} \mathrm{C}$.

The endometrium was separated from the fetal allantochorion by manual dissection. Strips of intercotyledonary endometrium were transferred to basic medium unless otherwise specified (see below). All the collected tissues were dissected into $1 \mathrm{~mm}^{3}$ pieces using a mechanical tissue chopper within $30 \mathrm{~min}$ after the animals were killed (McIlwain Laboratory Engineering Ltd, Surrey). The endometrial pieces were blotted with a sterile lens cleaning tissue and weighed to provide $0.15 \mathrm{~g}$ per culture dish. The tissues were placed on a metal grid (stainless steel, $30 \mathrm{~mm} \times 30 \mathrm{~mm} \times 0.5 \mathrm{~mm}$ ) cushioned with a layer of lens cleaning tissue in dishes ( $50 \mathrm{~mm} \times 15 \mathrm{~mm}$, single dent; $\mathrm{BDH})$ containing $6 \mathrm{ml}$ treatment medium (see below). In co-culture experiments the corpus luteum, pieces of allantochorion taken from the intercotyledonary regions and fetal cotyledon were also collected. The placentomes were separated manually by gentle squeezing into fetal and maternal components to obtain fetal cotyledon. The fetal side consisted of trophectoderm with underlying stromal tissue of mesodermal origin, although some maternal epithelial syncytium was still attached. The fetal tissues were dissected into pieces as described earlier. For culture of these tissues, endometrium ( $0.1 \mathrm{~g}$ per dish) was spread out in the middle of the metal grid and surrounded by finely chopped corpus luteum, fetal cotyledonary tissues or strips of allantochorion (0.1 g per dish, respectively).

The tissues were cultured at $37^{\circ} \mathrm{C}$ with $5 \% \mathrm{CO}_{2}$ for up to $96 \mathrm{~h}$ in a humidified incubator. At the end of the culture period, endometrial explants were collected for subsequent analysis. All the tissue pieces from each grid were mounted in cryo-M-bed (Bright, Huntingdon), frozen in dry ice and stored at $-80^{\circ} \mathrm{C}$. The viability of the tissue after $96 \mathrm{~h}$ in culture was checked by examining the histology of the explants by haematoxylin and eosin staining.

\section{Medium preparation}

The basic medium used was Dulbecco's modified Eagle's medium/nutrient F12 mix (1:1) with $15 \mathrm{mmol}$ Hepes $\mathrm{l}^{-1}$ (Gibco BRL, Paisley) containing penicillin sodium (50 iu ml-1;
NVS, Fenton, Stoke-on-Trent), streptomycin sulphate (50 mg $\mathrm{ml}^{-1}$; Sigma), $1.125 \mathrm{~g}$ sodium hydrocarbonate $\mathrm{l}^{-1}$ and bovine serum albumin (1.125 $\mathrm{g} \mathrm{l}^{-1}$; Sigma). The medium was filtered $(0.22 \mathrm{~mm}$ filter; Millipore, Watford). Finally, $1 \mathrm{ml}$ insulintransferrin-selenium mixture (ITS) was added to 11 filtered medium to provide final concentrations of $5 \mu \mathrm{g} \mathrm{l}^{-1}, 5 \mu \mathrm{g} \mathrm{l}^{-1}$ and $5 \mathrm{ng} \mathrm{l}^{-1}$, respectively. The medium was stored at $4^{\circ} \mathrm{C}$. Stock solutions of progesterone $\left(3.18 \mathrm{mmol} \mathrm{l}^{-1}\right)$ and oestradiol $\left(50 \mathrm{mmol} \mathrm{l}^{-1}\right)$ were prepared in absolute ethanol. These were then diluted to the working concentrations in basic medium through a serial dilution.

\section{Experimental treatments}

All treatments were tested on tissue collected from three separate ewes unless otherwise specified. Each treatment per animal was performed in triplicate.

Experimental group 1. This group included the following treatments: (i) control (basic medium); (ii) oestradiol $\left(0.1 \mu \mathrm{mol} \mathrm{l}^{-1}\right.$ and $\left.1 \mu \mathrm{mol} \mathrm{l}^{-1}\right)$; (ii) discontinuous progesterone $\left(0.1 \mu \mathrm{mol} \mathrm{l}^{-1}\right.$ and $\left.1 \mu \mathrm{mol} \mathrm{l} \mathrm{l}^{-1}\right)$; (iii) continuous progesterone $\left(1 \mu \mathrm{mol} \mathrm{l^{-1 }}\right)$; and (iv) fetal calf serum (FCS, $\left.5 \% \mathrm{v} / \mathrm{v}\right)$. The medium was changed every $24 \mathrm{~h}$.

All treatments except the continuous progesterone treatment had an interval of $2-4 \mathrm{~h}$ between the removal of the endometrium from the maternal system and culture in the treated medium. During this interval, the endometrium was processed in basic medium. For the continuous progesterone treatment, endometrium was placed into medium containing progesterone immediately after removal from the animal and was maintained in this throughout processing. All samples treated with oestradiol were collected at $0,12,24$ and $48 \mathrm{~h}$; the rest of the samples were collected at 0,48 and $96 \mathrm{~h}$.

Experimental group 2. This group contained the following treatments: (i) control (basic medium); co-culture of endometrial explants with (ii) corpus luteum, (iii) allantochorion, and (iv) fetal cotyledonary tissues. The medium was changed every $24 \mathrm{~h}$. The medium removed was collected and stored at $-20^{\circ} \mathrm{C}$. Tissue samples were collected at 0,48 and $96 \mathrm{~h}$.

\section{Progesterone radioimmunoassay}

The concentration of progesterone in the collected medium from the co-culture experiments was analysed by radioimmunoassay as described by Wathes and Porter (1982). The detection limit was $0.003 \mu \mathrm{mol} \mathrm{l}^{-1}$.

\section{In situ hybridization}

Sections ( $10 \mu \mathrm{m}$ thick) of endometrial explants frozen in blocks of cryo-M-bed were cut and thaw-mounted on slides coated with poly-L-lysine $\left(0.1 \mathrm{mg} \mathrm{ml}^{-1}\right)$. The sections were fixed in $4 \%(\mathrm{w} / \mathrm{v})$ paraformaldehyde in PBS $\left(0.13 \mathrm{~mol} \mathrm{NaCl}^{-1}\right.$, 
$\left.0.007 \mathrm{~mol} \mathrm{Na}_{2} \mathrm{HPO}_{4} \mathrm{l}^{-1}\right)$ for $5 \mathrm{~min}$, washed in PBS $(3 \times 2 \mathrm{~min})$, and dehydrated in $75 \%$ and then $95 \%$ absolute ethanol for $5 \mathrm{~min}$. The sections were stored in $95 \%$ absolute ethanol at $4^{\circ} \mathrm{C}$.

The in situ hybridization procedures were applied as described by Wathes et al. (1996a). Briefly, the oxytocin receptor DNA probe (antisense; 45mer synthetic oligonucleotide), end labelled with [ ${ }^{35}$ S]dATP (NEN Research Products, Stevenage; 100000 c.p.m. per $100 \mu$ l hybridization buffer per slide), was added to the sections, which were then covered with a parafilm coverslip and incubated at $43^{\circ} \mathrm{C}$ overnight. After incubation, the sections were washed at room temperature for $30 \mathrm{~min}$ and placed in $1 \times$ sodium saline citrate (SSC; $15 \mathrm{mmol}$ sodium chloride $\mathrm{l}^{-1}, 15 \mathrm{mmol}$ sodium citrate $\left.\mathrm{l}^{-1}, \mathrm{pH} 7.0\right)$ containing $0.2 \%(\mathrm{w} / \mathrm{v})$ sodium thiosulphate5 hydrate for $1 \mathrm{~h}$ at $55^{\circ} \mathrm{C}$. The slides were then dehydrated in a gradient of ethanol, air-dried and exposed to hyperfilm- $\beta_{\max }$ (Amersham International plc, Amersham) for 2 weeks. A labelled oligonucleotide of the sense sequence was used as the negative control for each sample. Sections from the uterus of a ewe in oestrus were used as the positive control in each batch of sections processed.

\section{Autoradiography}

The method was based on that described by Ayad et al. (1991). Sections ( $20 \mu \mathrm{m}$ thick) were cut from frozen explant samples, pre-washed in ice-cold phosphate buffer $(0.1 \mathrm{~mol}$ $\left.1^{-1}, \mathrm{pH} 7.4,0.1 \%(\mathrm{w} / \mathrm{v}) \mathrm{BSA}\right)$ without magnesium chloride $\left(\mathrm{MgCl}_{2}\right)$ and incubated with $300 \mu \mathrm{d}\left(\mathrm{CH}_{2}\right)_{5}$ [Tyr $(\mathrm{Me})^{2} \mathrm{Thr}^{4}$ Tyr $\mathrm{NH}_{2}{ }^{9}$ ]-vasotocin (25I-labelled oxy tocin receptor antagonist; 1250 c.p.m. ml- $\left.{ }^{-1}\right)$ in buffer containing $\mathrm{MgCl}_{2}\left(2.04 \mathrm{~g} \mathrm{l}^{-1}\right)$. This gave the maximum binding. The nonspecific binding solution containing excess unlabelled oxytocin $\left(10 \mathrm{mg} \mathrm{m}^{-1}\right.$; Bachem UK Ltd, Saffron Walden) was added to the control slides. The slides were then incubated at room temperature for $1 \mathrm{~h}$. After incubation, the slides were washed vigorously in fresh ice-cold phosphate buffer containing $\mathrm{MgCl}_{2}$ $(3 \times 1 \mathrm{~min})$, washed for $1 \mathrm{~min}$ in ice-cold distilled water, and then air-dried at room temperature. The slides were then exposed to hyperfilm- $\beta_{\max }$ for $48 \mathrm{~h}$.

\section{Photographic emulsions}

The procedures were similar to the instructions provided by the manufacturer (LM-1, Amersham International plc, Amersham). Dried slides were dipped vertically into the emulsion for $5 \mathrm{~s}$ at $43^{\circ} \mathrm{C}$ and allowed to dry horizontally for $10 \mathrm{~min}$ first at room temperature and then on a metal plate pre-cooled with dry ice. The slides were then placed into a light-tight box with anhydrous silica gel, sealed and incubated at $4^{\circ} \mathrm{C}$ for 3 weeks. After incubation, the slides were dipped into developer (Phenisol; Ilford Limited, Ilford) for $5 \mathrm{~min}$, stop bath $(0.5 \%(\mathrm{v} / \mathrm{v})$ acetic acid) for $1 \mathrm{~min}$, fixative $(47 \%(\mathrm{w} / \mathrm{v})$ sodium thiosulphate pentahydrate) for $10 \mathrm{~min}$ and then distilled water for at least $10 \mathrm{~min}$ before counterstaining with Harris' haematoxylin and eosin to identify the types of cell.

\section{Data analysis}

Images of the films from both the in situ hybridization and ${ }^{125} \mathrm{I}-$ labelled oxytocin receptor antagonist autoradiography experiments were quantified by measuring the absorbance of specific areas (identified using haematoxylin and eosin staining) using an image analysis system (Seescan plc, Cambridge). The results were expressed as arbitrary absorbance units on a linear scale from 0.01 to 2.1. Measurements were made of the sense and antisense images obtained from four sections per sample and three readings per section, giving a total of 12 readings per sample per time point. As oxytocin receptor expression was confined to the luminal epithelium, measurements were only taken from this type of cell, which was the only region to give a positive image on the film. Each area measured contained a minimum of 150 epithelial cells (see Fig. 1). The sense values were subtracted from the antisense values to produce a mean value of specific hybridization in each region for each sample. The inter-batch coefficient of variation (calculated from the control sections from a ewe in oestrus) was $12 \%$. All the samples from the same tissue culture experiment were processed for in situ hybridization at the same time to remove any inter-batch variation in the analysis of treatment effects. The intra-batch coefficient of variation (calculated from duplicate sections of the same sample) was $18 \%$.

Data from each treatment were analysed by a three-way ANOVA with the incubation time (h), the treatment effect (in comparison with the control at each time point) and the animal from which the tissue was obtained as factors. If the result from the initial ANOVA showed a significant treatment effect $(P<0.05)$, the data at each specific time point were subsequently analysed by Newman Keul's test to investigate the treatment effect. Similarly, the time effect was examined using the same method within the same treatment.

\section{Results}

\section{Spontaneous increase in oxytocin receptor expression in endometrial explants}

Data from all the experiments were pooled to define the changing pattern of oxytocin receptor expression over time in control tissues. Expression of oxytocin receptor mRNA in the unprocessed endometrium at 130-138 days of pregnancy was confined to the luminal epithelium and the concentration was $0.04 \pm 0.007$ (mean \pm SEM absorbance units, $n=6$ animals). The concentration of oxytocin receptor mRNA in chopped endometrial luminal epithelium collected at the start of culture $(0 \mathrm{~h})$ was $0.03 \pm 0.006$ absorbance units ( $n=12$ animals) and did not differ significantly from that in the untreated intact endometrial luminal epithelium. Oxytocin receptor mRNA started to increase spontaneously between 12 and $24 \mathrm{~h}$ of incubation and reached a peak at an absorbance of $0.21 \pm 0.025$ between 48 and $72 \mathrm{~h}$ (a significant increase, $P<0.0001 ; n=12$ animals), remaining at this concentration until $96 \mathrm{~h}$ (Figs 1 and 2). ${ }^{125}$ I-labelled oxytocin receptor antagonist binding showed a similar trend, except that the receptor binding started to increase between 0 and $12 \mathrm{~h}$, earlier than the upregulation of the mRNA. 
(a)

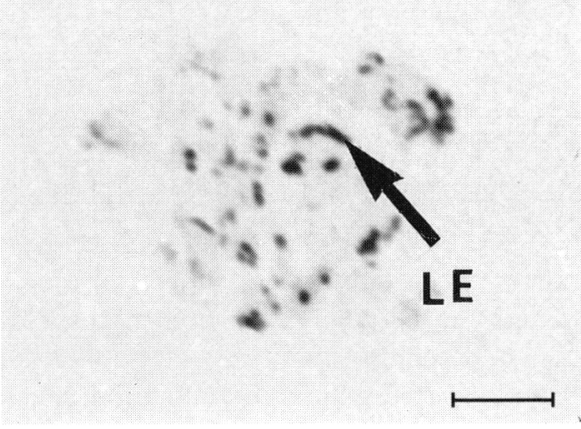

(c)
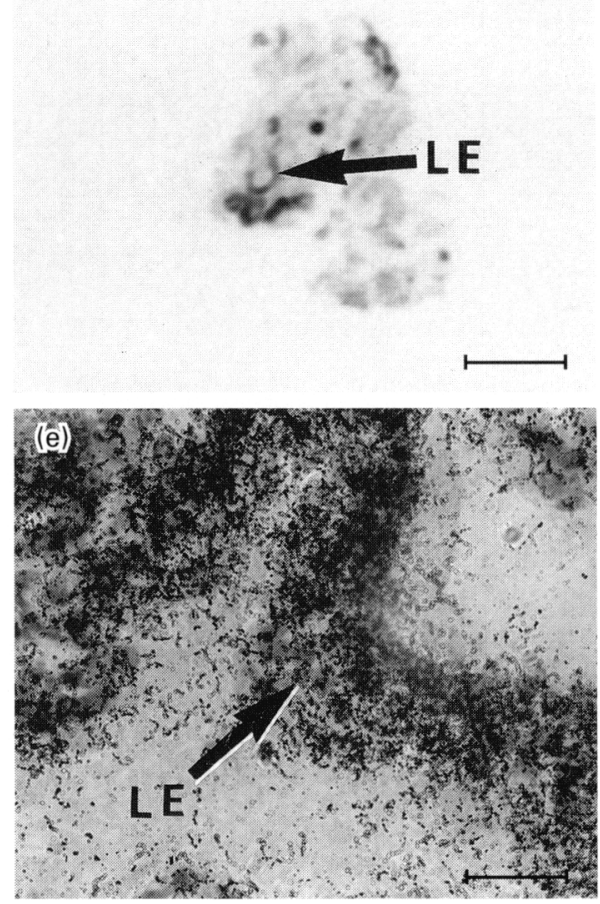

(b)

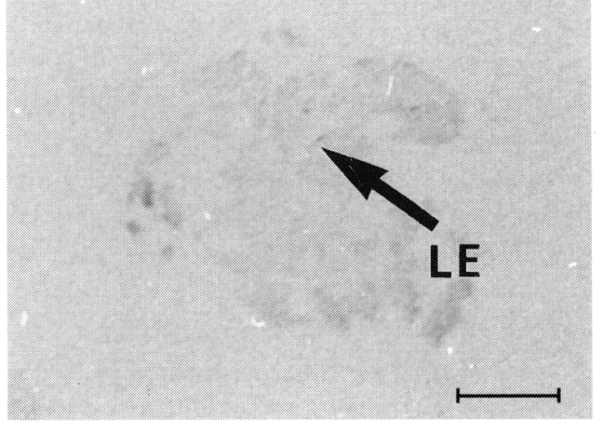

(d)

Fig. 1. (a) Expression of oxytocin receptors in explant cultures of intercotyledonary endometrium obtained from a ewe on day 135 of pregnancy after $48 \mathrm{~h}$ of incubation and localized using in situ hybridization and (b) the corresponding sense control. (c) Oxytocin binding sites localized using autoradiography with ${ }^{125} \mathrm{I}$-labelled oxytocin receptor antagonist and (d) nonspecific binding, containing excess unlabelled oxytocin peptide, used as the negative control. (e) Photographic emulsion showing that oxytocin receptor mRNA was expressed specifically in the endometrial luminal epithelium (LE) and (f) the corresponding sense control. Scale bars represent (a-d) $3 \mathrm{~mm}(\mathrm{e}, \mathrm{f}) 10 \mu \mathrm{m}$.

\section{Experimental group 1: hormone treatments}

Oestradiol $\left(0.1 \mu \mathrm{mol} \mathrm{l}^{-1}\right)$ upregulated the concentration of oxytocin receptor mRNA significantly after $12 \mathrm{~h}$ of incubation compared with the corresponding controls. There was no significant effect at 24 and $48 \mathrm{~h}$, and the final mRNA concentration was similar to that found in the controls (Table 1). Oestradiol $\left(0.1 \mu \mathrm{mol} \mathrm{l}^{-1}\right)$ also significantly increased the binding of ${ }^{125}$ I-labelled oxytocin receptor antagonist after $12 \mathrm{~h}$ of culture. This increase was no longer significant at $24 \mathrm{~h}$ and had disappeared by $48 \mathrm{~h}$ (Table 2). Oestradiol at a higher concentration $\left(1 \mu \mathrm{mol} \mathrm{l^{-1 }}\right)$ had no effect on oxytocin receptor mRNA expression.

Discontinuous progesterone treatment at both 0.1 and $1.0 \mu \mathrm{mol} \mathrm{l}^{-1}$ (present from when the processed tissue was placed on the grids, approximately $2-4 \mathrm{~h}$ after removal from the animal) had no significant effect on the spontaneous increase in the concentration of oxytocin receptor mRNA at either 48 or $96 \mathrm{~h}$. The continuous progesterone treatment $\left(1 \mu \mathrm{mol} \mathrm{l}^{-1}\right.$, present from immediately after tissue removal from the animal) inhibited oxytocin receptor expression at $48 \mathrm{~h}$ of incubation, but this inhibitory effect disappeared by $96 \mathrm{~h}$ of 

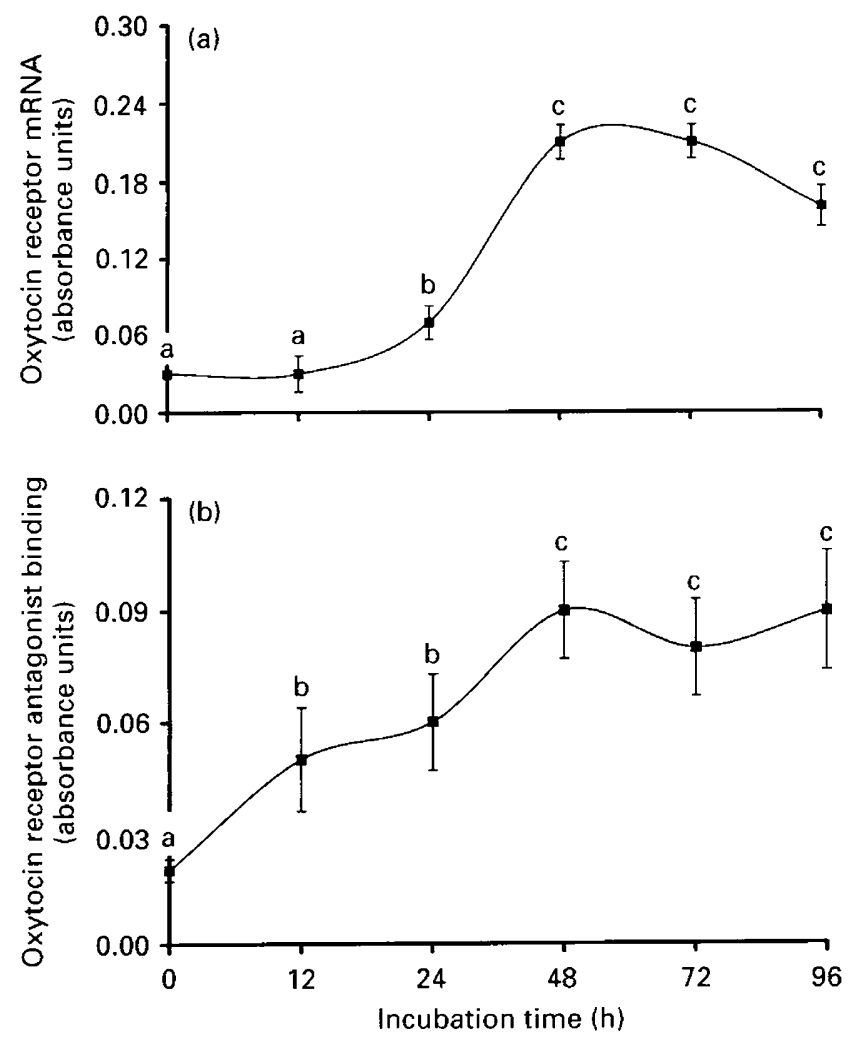

Fig. 2. The concentration of (a) oxytocin receptor mRNA and (b) oxytocin receptor binding localized in the luminal epithelium using in situ hybridization and autoradiography with ${ }^{125}$ I-labelled oxytocin receptor antagonist. The results are expressed as absorbance units (mean $\pm \mathrm{SEM}, n=12$ animals). Samples were collected at regular intervals from the start of culture $(0 \mathrm{~h})$. A significant and spontaneous upregulation of oxytocin receptor mRNA was observed between 12 and $48 \mathrm{~h}$. The oxytocin receptor mRNA concentration reached peak values between 48 and $72 \mathrm{~h}$, and remained high until $96 \mathrm{~h}$. The receptor binding activity increased at a constant rate from $0 h$, peaked at $48 \mathrm{~h}$, and remained high at $96 \mathrm{~h}$. Significant differences are indicated: $b>a, P<0.01 ; c>b, P<0.01$.

incubation (Table 1). In contrast, neither progesterone treatment showed any effect on the binding of ${ }^{125} \mathrm{I}$-labelled oxytocin receptor antagonist at either time point (Table 2).

There was no significant effect of $5 \%$ FCS on either the timing of the spontaneous increase in expression of oxytocin receptor $m R N A$ or in the final concentration reached (Table 1 ).

\section{Experimental group 2: co-culture experiments}

The co-culture of endometrium with corpus luteum significantly inhibited expression of oxytocin receptor mRNA in the endometrial luminal epithelium after $48 \mathrm{~h}$ of incubation, but the difference was no longer significant by $96 \mathrm{~h}$ (Table 3). Co-culture of fetal cotyledonary tissues and allantochorion with maternal endometrium did not have any significant effect on the expression of oxytocin receptor mRNA at either 48 or $96 \mathrm{~h}$. Neither of the co-culture treatments had any significant effect on the binding of ${ }^{125} \mathrm{I}-$ labelled oxytocin receptor antagonist (Table 3).
The corpus luteum explants secreted significant concentrations of progesterone into the medium at both 48 and $96 \mathrm{~h}\left(0.6 \pm 0.21\right.$ and $0.2 \pm 0.1 \mu \mathrm{mol} \mathrm{l}^{-1}$, respectively). There were low but detectable concentrations of progesterone in the medium collected from the co-cultures with fetal cotyledon $\left(0.003 \pm 0.0012\right.$ and $0.001 \pm 0.0004 \mu \mathrm{mol} l^{-1}$ at 48 and $96 \mathrm{~h}$, respectively), whereas cultures containing only endometrium produced no detectable progesterone at either time point (concentration in medium $<0.0003 \mu \mathrm{mol} \mathrm{l}^{-1}$ ).

\section{Discussion}

The experiments reported here were designed to provide further information on the effect of steroid hormones and the involvement of tissue-specific factors on the expression of endometrial oxytocin receptors in late pregnancy. The advantage of using explant culture over cell culture is that any regulatory effect from endometrial stromal cells is preserved. This provides a better system to evaluate the requirement of local regulatory factors and hence a more accurate observation on the regulation of expression of oxytocin receptors. The combined use of in situ hybridization and ${ }^{125} \mathrm{I}$-labelled oxytocin receptor antagonist autoradiography on the same samples allowed a direct comparison to be made between regulation of expression of oxytocin receptors at the transcriptional and post-transcriptional levels, and determination of the cellular localization. This study shows that in pregnant endometrium, expression of oxytocin receptors is confined to the epithelium.

The endometrial explants used in this study were also cultured in fully defined serum-free medium to elucidate the effect of the individual treatments. However, results from the treatment group in which FCS was included were similar to those found in the serum-free controls with respect to mRNA expression. This finding, coupled with observations of tissue morphology, confirmed that the endometrial explants could survive in serum-free medium for at least $96 \mathrm{~h}$. Furthermore, the concentration of oxytocin receptor $\mathrm{mRNA}$ and ${ }^{125} \mathrm{I}$ labelled oxytocin receptor antagonist binding measured at 48 and $96 \mathrm{~h}$ in the explants were comparable to those reported in endometrial epithelium from ewes undergoing spontaneous labour (Wathes et al., 1996a).

The present study and other reports on endometrial explants of nonpregnant sheep (Sheldrick et al., 1993) and endometrial epithelial cultures of cows (Horn $e t$ al., in press) show that endometrial oxytocin receptor concentrations increase spontaneously in culture. It is unclear what causes this upregulation. It is possible that maximal expression of oxytocin receptors may require a specific factor that is either inactivated or suppressed for most of the time within the normal uterine environment. This factor must be produced by the endometrium of both pregnant and nonpregnant animals and is unlikely to be oestradiol for the reasons discussed below. Alternatively, removal of the endometrium from the maternal system may introduce stress into the explant tissues such as cell death, changes in osmolarity and temperature shock during the processing procedures. Signals such as these may trigger an acute response (Dudley et al., 1993) which subsequently influences expression of the oxytocin receptor. 
Table 1. Effect of hormone treatment on expression of oxytocin receptor mRNA in the luminal epithelium of endometrial explants from late pregnant ewes

\begin{tabular}{lcccc}
\hline & \multicolumn{4}{c}{ Time in culture } \\
\cline { 2 - 5 } Treatment & $12 \mathrm{~h}$ & $24 \mathrm{~h}$ & $48 \mathrm{~h}$ & $96 \mathrm{~h}$ \\
\hline Control & $0.03 \pm 0.014^{\mathrm{a}}$ & $0.07 \pm 0.029$ & $0.19 \pm 0.061$ & $\mathrm{nt}$ \\
Oestradiol $\left(0.1 \mu \mathrm{mol}^{-1}\right)$ & $0.06 \pm 0.024^{\mathrm{b}}$ & $0.10 \pm 0.028$ & $0.16 \pm 0.047$ & $\mathrm{nt}$ \\
Oestradiol $\left(1.0 \mu \mathrm{mol} \mathrm{l}^{-1}\right)$ & $0.03 \pm 0.019$ & $0.07 \pm 0.029$ & $0.25 \pm 0.033$ & $\mathrm{nt}$ \\
Control & $\mathrm{nt}$ & $\mathrm{nt}$ & $0.22 \pm 0.021^{\mathrm{c}}$ & $0.21 \pm 0.026$ \\
Continuous progesterone $\left(1.0 \mu \mathrm{mol} \mathrm{l}^{-1}\right)$ & $\mathrm{nt}$ & $\mathrm{nt}$ & $0.12 \pm 0.040^{\text {d }}$ & $0.21 \pm 0.070$ \\
Discontinuous progesterone $\left(1.0 \mu \mathrm{mol}^{-1}\right)$ & $\mathrm{nt}$ & $\mathrm{nt}$ & $0.18 \pm 0.052$ & $0.25 \pm 0.100$ \\
Discontinuous progesterone $\left(0.1 \mu \mathrm{mol}^{-1}\right)$ & $\mathrm{nt}$ & $\mathrm{nt}$ & $0.20 \pm 0.032$ & $\mathrm{nt}$ \\
Control & $\mathrm{nt}$ & $\mathrm{nt}$ & $0.18 \pm 0.061$ & $0.15 \pm 0.033$ \\
Fetal calf serum $(5 \% \mathrm{v} / \mathrm{v})$ & $\mathrm{nt}$ & $\mathrm{nt}$ & $0.20 \pm 0.038$ & $0.15 \pm 0.031$ \\
\hline
\end{tabular}

Each treatment was tested in triplicate on tissues from three ewes. Results are expressed as absorbance units (mean \pm SEM) and are analysed in comparison with tissues from the corresponding controls from the same time point.

Discontinuous progesterone treatment was in basic control medium for approximately $4 \mathbf{h}$ during tissue processing, whereas continuous progesterone treatment was processed in medium containing progesterone.

Data were analysed by ANOVA with time, treatment and animal as factors. Significant treatment effects at a particular time point are shown: $\mathrm{b}>\mathrm{a}$ and $\mathrm{d}<\mathrm{c} ; P<0.01$. nt, not tested.

Table 2. Effect of steroid treatment on ${ }^{125}$ I-labelled oxytocin receptor antagonist binding in the luminal epithelium of endometrial explants from late pregnant ewes

\begin{tabular}{lcccc} 
& \multicolumn{4}{c}{ Time in culture } \\
\cline { 2 - 5 } Treatment & $12 \mathrm{~h}$ & $24 \mathrm{~h}$ & $48 \mathrm{~h}$ & $96 \mathrm{~h}$ \\
\hline Control & $0.03 \pm 0.010^{\mathrm{a}}$ & $0.04 \pm 0.014$ & $0.09 \pm 0.020$ & $\mathrm{nt}$ \\
Oestradiol $\left(0.1 \mu \mathrm{mol} \mathrm{l}^{-1}\right)$ & $0.06 \pm 0.012^{\mathrm{b}}$ & $0.07 \pm 0.014$ & $0.10 \pm 0.033$ & $\mathrm{nt}$ \\
& & & & \\
Control & nt & nt & $0.06 \pm 0.012$ & $0.10 \pm 0.024$ \\
Continuous progesterone $\left(1.0 \mu \mathrm{mol} \mathrm{l}^{-1}\right)$ & nt & nt & $0.06 \pm 0.024$ & $0.08 \pm 0.007$ \\
Discontinuous progesterone $\left(1.0 \mu \mathrm{mol} \mathrm{l}^{-1}\right)$ & nt & nt & $0.05 \pm 0.024$ & $0.10 \pm 0.014$ \\
\hline
\end{tabular}

Each treatment was tested in triplicate on tissues from three ewes. Results are expressed as absorbance units (mean \pm SEM) and are analysed in comparison with tissues from the corresponding controls from the same time point.

Discontinuous progesterone treatment was in basic control medium for approximately $4 \mathrm{~h}$ during tissue processing, whereas continuous progesterone treatment was processed in medium containing progesterone.

Significant treatment effects at a particular time point are shown: $b>a ; P<0.01$. nt, not tested.

Table 3. Effect of co-culture on expression of oxytocin receptor mRNA and ${ }^{125} \mathrm{I}$-labelled oxytocin receptor antagonist binding in the luminal epithelium of endometrial explants from late pregnant ewes

\begin{tabular}{|c|c|c|c|c|}
\hline \multirow[b]{3}{*}{ Treatment } & \multicolumn{4}{|c|}{ Time in culture } \\
\hline & $48 \mathrm{~h}$ & $96 \mathrm{~h}$ & $48 \mathrm{~h}$ & $96 \mathrm{~h}$ \\
\hline & \multicolumn{2}{|c|}{$\begin{array}{l}\text { Oxytocin receptor } \\
\text { mRNA }\end{array}$} & \multicolumn{2}{|c|}{$\begin{array}{l}{ }^{125} \text { I-labelled oxytocin receptor } \\
\text { antagonist binding }\end{array}$} \\
\hline Control & $0.20 \pm 0.005^{a}$ & $0.19 \pm 0.102$ & $0.07 \pm 0.002$ & $0.08 \pm 0.023$ \\
\hline Corpus luteum & $0.10 \pm 0.005^{b}$ & $0.15 \pm 0.021$ & $0.05 \pm 0.002$ & $0.06 \pm 0.033$ \\
\hline Control & $0.11 \pm 0.038$ & $0.10 \pm 0.029$ & $0.07 \pm 0.010$ & $0.07 \pm 0.043$ \\
\hline Fetal cotyledon & $0.12 \pm 0.029$ & $0.11 \pm 0.026$ & $0.04 \pm 0.010$ & $0.06 \pm 0.014$ \\
\hline Allantochorion & $0.14 \pm 0.023$ & $0.10 \pm 0.026$ & $0.06 \pm 0.012$ & $0.05 \pm 0.038$ \\
\hline
\end{tabular}

Each treatment was tested in triplicate on tissues from three ewes. Results are expressed as absorbance units (mean \pm SEM) and are analysed in comparison with tissues from the corresponding controls from the same time point.

Significant treatment effects at a particular time point are shown: $b<a ; P<0.01$. 
Many studies in vivo have shown the positive effect of oestradiol on expression of oxytocin receptors. However, a number of reports indicate that the action of oestradiol can be biphasic, both inducing and inhibiting the expression of oxytocin receptors depending on the concentration and duration of treatment (Vallet et al., 1990; Larcher et al., 1995; Wathes et al., 1996b). The oxytocin receptor gene promoter contains three half-palindromic oestrogen responsive elements (Inoue et al., 1994), indicating that oestrogen may regulate the expression of the oxytocin receptor directly. However, in the present study, oestradiol was not required for the upregulation of oxytocin receptor mRNA or binding in the luminal epithelial cells and there was no significant difference between the control and oestradiol treatments at $48 \mathrm{~h}$. This finding is consistent with studies in vitro showing that binding of tritiated oxytocin to the endometrium increases significantly and spontaneously up to $96 \mathrm{~h}$ in culture. Oestradiol either had no effect $\left(<1 \mu \mathrm{mol} \mathrm{l}^{-1}\right)$ or inhibited the binding activity at a high concentration $\left(100 \mu \mathrm{mol} \mathrm{l}^{-1}\right)$ in ovine endometrial explants and bovine epithelial cell cultures after $96 \mathrm{~h}$ of incubation (Sheldrick and Flick-Smith, 1993; Horn et al., in press). Therefore, there is a discrepancy between the action of oestradiol in vivo and in vitro. In the present study, the effect of oestradiol was examined at an earlier series of time points from $12 \mathrm{~h}$ after the start of culture. This approach was chosen to determine whether oestrogen influences the rate or timing of the spontaneous increase, without necessarily causing a greater final concentration. The results of this study are in agreement with previous reports that there was no effect at $48 \mathrm{~h}$. However, oestradiol did stimulate the increase in expression of oxytocin receptor mRNA to occur slightly earlier during the culture. This finding indicates that oestradiol either enhances the efficiency of the transcriptional process or potentiates the half-life of oxytocin receptor mRNA such that a greater amount accumulates. It has been suggested that oestradiol prolongs the poly(A)-tail of the oxytocin receptor mRNA to stabilize the transcript in the kidney (Breton et al., 1996). Oestradiol also stimulated the binding of ${ }^{125}$ I-labelled oxytocin receptor antagonist significantly after $12 \mathrm{~h}$ of incubation, indicating that the effect of oestradiol on oxytocin receptor expression is at the transcriptional level.

Progesterone can inhibit the expression of oxytocin receptors in steroid-treated ovariectomized sheep in vivo, but the inhibitory effect on the luminal epithelial cells cannot be maintained for longer than about 12-14 days (Vallet et al., 1990; Wathes et al., 1996b). In the present study, progesterone did not significantly inhibit the expression of oxytocin receptors in vitro if the endometrium was temporarily exposed to a progesterone-free environment for about $4 \mathrm{~h}$. In contrast, continuous progesterone treatment significantly inhibited the upregulation of the oxytocin receptor mRNA at $48 \mathrm{~h}$, but the effect could not be sustained for $96 \mathrm{~h}$. This indicates that progesterone inhibits oxytocin receptor expression indirectly. Unlike oestradiol, the binding activity of the ${ }^{125}$ I-labelled oxytocin receptor antagonist was not significantly different from the control in both progesterone treatments during the period studied, although transcription of the oxytocin receptor gene was inhibited in the continuous progesterone treatment at $48 \mathrm{~h}$. This result implies that progesterone regulates oxytocin receptor expression at the transcriptional level. However, post-transcriptional control of oxytocin receptor expression may not be influenced by progesterone.

These data are consistent with various in vitro experiments indicating that a continuous progesterone environment is essential (even if not sufficient on its own) to keep oxytocin receptor expression at a basal level. Administration of RU486 (a progesterone antagonist) or epostane (a progesterone synthase inhibitor) initiates parturition in late pregnant cows or sheep (Ledger et al., 1985; Li et al., 1991) and similar experiments with RU486 in rats showed that treatment resulted in an increase in uterine oxytocin receptor expression (Fang et al., 1996, 1997). In the present study, disruption of the progesterone-dominated environment for as little as $4 \mathrm{~h}$ was sufficient to remove the inhibitory effect of progesterone. This result also favours the proposed mechanism that once the stimulatory factors are switched on, they either cannot be switched off or antagonize the inhibitory effect of progesterone.

Co-culture of endometrium with corpus luteum inhibited the spontaneous upregulation of oxytocin receptors in the endometrial luminal epithelium. This is consistent with previous findings in nonpregnant sheep (Sheldrick et al., 1993). This implies that the inhibitor of oxytocin receptor expression secreted from the cyclic corpus luteum remains active during late pregnancy. Although the inhibitory pattern was similar to that of the continuous progesterone treatment described earlier, the inhibitory effect of the corpus luteum remained even when the endometrium was exposed to a progesterone-free environment for $4 \mathrm{~h}$, whereas the discontinuous progesterone treatment failed to suppress oxytocin receptor expression. The progesterone concentration tested $\left(1 \mu \mathrm{mol} \mathrm{l}^{-1}\right)$ was in the same concentration range as the progesterone output by the luteal co-cultures $\left(0.6 \mu \mathrm{mol} \mathrm{l}^{-1}\right)$. Therefore, the unknown factor is unlikely to be progesterone. Although such a factor could modulate oxytocin receptor expression, it may not play an essential role because ovariectomy of sheep in midpregnancy does not significantly affect pregnancy outcome (Liggins and Thorburn, 1994).

Interferon $\tau$ produced by the trophoblast in early pregnancy in sheep strongly inhibits the expression of oxytocin receptors (Stewart et al., 1992), which is an essential step to the establishment of pregnancy. The trophoblast stops producing interferon $\tau$ at about 3 weeks after mating (Flint et al., 1994b). Although oxytocin receptor expression in the endometrium returns after the disappearance of interferon $\tau$ on about day 22 of pregnancy, its concentration remains low throughout gestation (Wathes et al, 1996a). In the present study, co-culture of endometrium with fetal placental tissues or allantochorion did not have any regulatory effect on oxytocin receptor expression. Therefore, the suppression of oxytocin receptor mRNA during pregnancy is unlikely to be controlled directly by the placental tissues after the critical period that is necessary for the maternal recognition of pregnancy.

In summary, oestradiol facilitates the expression of oxytocin receptors in late pregnant endometrium, probably via a transcriptional mechanism. However, it is not essential for the full upregulation of oxytocin receptor transcription in 
the epithelium. The spontaneous increase in oxytocin receptor expression in culture probably involves removal of an unknown specific regulator, which may be controlled by progesterone at the transcriptional, but not at the posttranscriptional level. An environment dominated continuously by progesterone is required to suppress the upregulation of oxytocin receptors. The withdrawal of progesterone for a brief period is sufficient to switch on oxytocin receptor expression, and the inhibitory effect of progesterone is subsequently irrecoverable. This mechanism is not influenced directly by fetal placental tissues, but it may be modulated by specific factors from the corpus luteum.

The authors would like to thank John Thompson and David Manners for care of the animals, and the Royal Veterinary College for financial support. The oxytocin receptor antagonist was kindly supplied by M. Manning.

\section{References}

Ayad VJ, Guldenaar SEF and Wathes DC (1991) Characterization and localization of oxytocin receptors in the uterus and oviduct of the nonpregnant ewe using an iodinated receptor antagonist Journal of Endocrinology 128 187-195

Breton C, Neculcea J and Zingg HH (1996) Renal oxytocin receptor messenger ribonucleic acid: characterization and regulation during pregnancy and in response to ovarian steroid treatment Endocrinology 137 2711-2717

Cerbito WA, Miyamoto A, Sauerwein H, Wijayaguwardane MPB, Ohtani M, Takagi $M$ and Sato K (1997) Evidence for uterine horn differences in local concentrations of oxytocin, oxytocin receptor and prostaglandin $\mathrm{F}_{2}$ during the estrous cycle and early pregnancy Reproduction in Domestic Animals 32 161-165

Dudley DJ, Trautman MS and Mitchell MD (1993) Inflammatory mediators regulate interleukin-8 production by cultured gestational tissues: evidence for a cytokine network at the chorio-decidual interface Journal of Clinical Endocrinology and Metabolism 76 404-410

Fang X, Wong S and Mitchell BF (1996) Relationships among sex steroids, oxytocin and their receptors in the rat uterus during late gestation and at parturition Endocrinology 137 3213-3219

Fang X, Wong S and Mitchell BF (1997) Effects of RU486 on estrogen, progesterone, oxytocin and their receptors in the rat uterus during late gestation Endocrinology 138 2763-2768

Flint APF, Lamming GE, Stewart HJ and Abayasekara DRE (1994a) The role of the endometrial oxytocin receptor in determining the length of the sterile oestrous cycle and ensuring maintenance of luteal function in early pregnancy in ruminants Philosophical Transactions of the Royal Society of London Series B - Biological Sciences 344 291-304

Flint APF, Guesdon FMJ and Stewart HJ (1994b) Regulation of trophoblast interferon gene expression Molecular and Cellular Endocrinology 100 93-95

Fuchs AR, Husslein P and Fuchs F (1981) Oxytocin and the initiation of human parturition: II. Stimulation of prostaglandin production in human decidua by oxytocin American Journal of Obstetrics and Gynecology 141 694-697

Fuchs AR, Behrens O, Helmer H, Liu CH, Barros CM and Fields MJ (1990) Oxytocin and vasopressin receptors in bovine endometrium and myometrium during the estrus cycle and early pregnancy Endocrinology 127 629-636

Fuchs AR, Helmer H, Chang SM and Fields MJ (1992a) Concentration of oxytocin receptors in the placenta and fetal membranes of cows during pregnancy and labour Journal of Reproduction and Fertility 96 775-783

Fuchs AR, Helmer H, Behrens O, Liu HC, Antonian L, Chang SM and Fields MJ (1992b) Oxytocin and bovine parturition: a steep rise in endometrial oxytocin receptors precedes onset of labor Biology of Reproduction 47 937-944

Horn S, Bathgate $\mathbf{R}$, Lioutus $\mathrm{C}$, Bracken $\mathbf{K}$ and Ivell $\mathbf{R}$ Bovine endometrial epithelial cells as a model system to study oxytocin receptor regulation Human Reproduction Update 4 (in press)

Inoue T, Kimura T, Azuma C, Inazawa J, Takemura M, Kikuchi T, Kubota Y, Ogita K and Saji F (1994) Structural organization of the human oxytocin receptor gene Journal of Biological Chemistry 26932 451-32 456

Larcher A, Neculcea J, Breton C, Arslan A, Rozen F, Russo C and Zingg HH (1995) Oxytocin receptor gene expression in the rat uterus during pregnancy and the oestrous cycle and in response to gonadal steroid treatment Endocrinology 136 5350-5356

Ledger WL, Webster MA, Anderson ABM and Turnull AC (1985) Effect of inhibition of prostaglandin synthesis on cervical softening and uterine activity during ovine parturition resulting from progesterone withdrawal induced by epostane fournal of Endocrinology 105 227-233

Li YF, Perezgrovas R, Gazal OS, Schwabe C and Anderson L (1991) Antiprogesterone, RU 486, facilitates parturition in cattle Endocrinology 129 $765-770$

Liggins GC and Thorburn GD (1994) Initiation of parturition. In Marshall's Physiology of Reproduction Vol. 3 Pregnancy and Lactation pp 907-908 Ed. GE Lamming. Chapman \& Hall, London

Parry LJ, Bathgate RAD, Shaw G, Renfree MB and Ivell R (1997) Evidence for a local fetal influence on myometrial oxytocin receptors during pregnancy in the tammar wallaby (Macropus eugenii) Biology of Reproduction $56200-207$

Pimentel G, Poore ER and Nathanielsz PW (1989) The effect of continuous or pulsatile administration of oxytocin to ewes at 126 to 136 days' gestation on myometrial activity and fetal oxygenation American Journal of Obstetrics and Gynecology 160 242-247

Roberts RM, Leaman DW and Cross JC (1992) Role of interferons in maternal recognition of pregnancy in ruminants Proceedings of the Society for Experimental Biology and Medicine 200 7-18

Sheldrick EL and Flick-Smith HC (1993) Effect of ovarian hormones on oxy tocin receptor concentrations in explants of uterus from ovariectomized ewes Journal of Reproduction and Fertility $97241-245$

Sheldrick EL, Flick-Smith HC and Dos Santos Cruz GJ (1993) Oxytocin receptor binding activity in cultured ovine endometrium Journal of Reproduction and Fertility 98 521-528

Soloff MS (1985) Oxytocin receptors and mechanism of oxytocin action. In Oxytocin: Clinical and Laboratory Studies pp 259-276 Eds JA Amico and AG Robinson. Elsevier Science Publishers BVC

Stewart HJ, Guesdon FMJ, Payne JH, Charleston B, Vallet JL and Flint APF (1992) Trophoblast interferons in early pregnancy of domestic ruminants Joumal of Reproduction and Fertility Supplement 45 59-68

Stevenson KR, Riley PR, Stewart HJ, Flint APF and Wathes DC (1994) Localization of oxytocin receptor mRNA in the ovine uterus during the oestrous cycle and early pregnancy Journal of Molecular Endocrinology 12 93-105

Sugimoto Y, Yamasaki A, Segi E et al. (1997) Failure of parturition in mice lacking the prostaglandin $F$ receptor Science 277 681-683

Vallet JL, Lamming GE and Batten M (1990) Control of endometrial oxytocin receptor and uterine response to oxytocin by progesterone and oestradiol in the ewe Journal of Reproduction and Fertility 90 625-634

Wathes DC and Porter DG (1982) Effect of uterine distension and oestrogen treatment on gap junction formation in the myometrium of the rat Journal of Reproduction and Fertility 65 497-505

Wathes DC and Lamming GE (1995) The oxytocin receptor, luteolysis and the maintenance of pregnancy fournal of Reproduction and Fertility Supplement 49 53-67

Wathes DC, Flick-Smith $H$, Leung ST, Stevenson KR, Meier S and Jenkin G (1996a) Oxytocin receptor development in ovine uterus and cervix throughout pregnancy and at parturition as determined by in situ hybridization analysis Journal of Reproduction and Fertility 106 23-31

Wathes DC, Mann GE, Payne JH, Riley PR, Stevenson KR and Lamming GE (1996b) Regulation of oxytocin, oestradiol and progesterone receptor concentrations in different uterine regions by oestradiol, progesterone and oxytocin in ovariectomized ewes fournal of Endocrinology 151 375-393

Wu WX, Verbalis JG, Hoffman GE, Derks JB and Nathanielsz PW (1996) Characterization of oxytocin receptor expression and distribution in the pregnant sheep uterus Endocrinology 137 722-728 